\title{
The Properties Of The Shadow Banking In China
}

\section{Zafer ADALI ${ }^{1}$}

\section{ARTICLE INFO}

Article History:

Date Submitted: 06.08.2016

Date Accepted: 27.12.2016

\section{JEL Classification:}

G18

G20

G28

Keywords:

The Shadow Banking

The State Capitalism

The Informal Finance

\section{ABSTRACT}

The aim of this study is to define the properties of the shadow banking system in China. The shadow banking system has been paid attention since the subprime crisis because the spread of this finance form over the all around world was one of the most significant causes of the subprime crisis. The shadow banking is nourished from the Chinese state capitalism which is designed to allocate loans to important industries so SME are dependent on the shadow banking. Since excessively increase in leverage through financial engineering and purpose-made state capitalism create irresistible burden on financial market, the shadow banking system is by far the important factors in order to build stable financial market. While considering these issues, it was understood that the shadow banking system is significant issue in order to build strong financial efficiency and stability.

\footnotetext{
${ }^{1}$ Arş. Gor. Artvin Çoruh Üniversitesi, Hopa İktisadi ve İdari Bilimler Fakültesi, zaferadali@artvin.edu.tr
} 


\section{Özet}

Bu çalışmanın amacı, Çin'deki gölge bankacılık sisteminin özelliklerini tanımlamaktır. Gölge bankacılık sistemine, subprime krizinden beri dikkat çekilmektedir. Çünkü bu finans formunun tüm dünyaya yayılması subprime krizinin en önemli nedenlerinden biridir. Gölge bankacılığı, önemli sanayilere kredi tahsis etmek üzere tasarlanan Çin devlet kapitalizminden beslenmektedir. Bu nedenle KOBİ’ler gölge bankacılığına bağımlıdır. Finansal mühendislik ve özel bir amaçla yapılan devlet kapitalizmi yoluyla kaldıracın aşırı derecede artması, finansal piyasaya dayanılmaz bir yük oluşturduğundan, gölge bankacılık sistemi istikrarlı bir finansal piyasa oluşturmak için önemli faktörlerden biri haline gelmiştir. Bu noktalar göz önüne alındığında gölge bankacılığı sisteminin güçlü finansal verimlilik ve istikrar sağlama konusunda dikkate değer olduğu anlaşılmaktadır.

Anahtar Kelimeler: Gölge Bankacılığg, Devlet Kapitalizmi, Resmi Olmayan Finans

\section{Introduction}

The shadow banking system has been paid attention since the subprime crisis because the spread of this finance form over the all around world was one of the most significant causes of the subprime crisis. Paul Mc-Culle is the first economist who has coined the shadow banking term(Gandhi,2015). This finance form is so akin to traditional banking system and composed of financial intermediaries but shadow banking exempts from supervision and regulatory. Though the shadow banks offer credit intermediation, they manage outside the usual banking system(Jackson,2013).In addition to supervision and regulatory, taking deposits is other the most important difference only the traditional banks are allowed to take deposits. As for the shadow banks' the short term funding, repos, money market mutual fund shares and repos are the major short term funds for the shadow banks. All of them can substitute deposits and provide funds for the shadow banks. In addition to the 2008 subprime financial crisis, especially in China, the incentivized stimulate plan has been brought into force. Since these funds are quiet vulnerable to cash flow similar to the banks'collapse danger in insolvency and the shadow banks refer to legal black holes regarding to their actions, the shadow banks are able to again induce a globally financial crisis. 
In spite of vagueness in the shadow banking system, structured investment vehicles(SIV), asset-backed commercial paper(ABCP),credit default swaps(CDS) and assetbacked securities (ABS) are main finance vehicles also finance companies, securities lenders, money market mutual funds and trust companies constitute the shadow banking system. Simply, The Federal Saving Bank (FSB) has showed a definition that the shadow banking system contains activities and entities without the regular banking supervision (Tucker 2014).On the other hand, there is significant interconnectedness between the shadow banking and the traditional banks in China as well USA. For example, the loans of microfinance companies are provided by the rational banks. Another example, especially in USA, the mortgage payment in traditional banks securitisated by financial derivatives is offered to shadow banks so that traditional banks can not only obtain liquidity but also the shadow banks can increase assets in their portfolio but these process increases leverage and demonstrate high system risk because the risk is not able to properly evaluate(Weinland 2015).With respect to the global financial crisis, it is a good point that the collapse of the mortgage system is associated with above mention risk. In order to free up the traditional banks capital, the financial engineering as abovementioned securitization was employment to offer the subprime mortgage thus this additional capital freed up by securitization used to offer further loans so that the leverage excessively increased. As matter of fact, the delinquency of the shadow banking distorted global financial stability and ultimately caused financial crisis, which spread quickly across borders.

Chinese state capitalism is made of financial repression and directed credit. Both of features grant privilege state-owned enterprise over private firms. However, 95 percent of registered firms are composed of small and medium firm which does not directly benefit from China's pattern of state capitalism but state-affiliated firms are dominant on given loans as well China's stock markets so that small and medium firms have substantially trusted on informal financial vehicles. Especially, after the new technologies of finance and too prolonged low interest rate, informal finance mechanism has flourished. For example, the spread of internet have stimulated the magnitude of internet financing instruments. Generally, informal finance vehicles are related to saving and investment instrument, which are either regulated or sanctioned by the People's Bank of China. Indeed, most of them are not legally 
forbidden. Furthermore, since the formal financial system is controlled and operated by the Chinese state capitalism, shadow banking will increasingly continue also shadow banking system will go on continuing to play significant role for search for yield and the need of fund for local government. The some of the informal finances are made of credit guarantee companies, pawnshop and investment companies(Tsai,2015).

Clearly understanding of the shadow banking is mandatory for policy because reducing systematic risk in financial market is main required for policy makers; yet, comprehensive policies about the shadow banking system are not obvious. Thus, better measuring and monitoring the shadow system are to clearly put in effect. In the study, the shadow banking system have been tried to briefly examine and generate the features of the shadow banks. An important initial point to figuring outthis system is the Chinese state capitalism and its growth strategies. Even though there is sufficient literature about Chinese financial system, the literature about the shadow banking system is insufficient. Owing to this situation, it can be said that this study makes an important contribution to the literature.

\section{Shadow Banks In China}

In terms of state capitalism in China, capital is intentionally allocated to the most significant export industrial sectors and firms, whichdirectly and proprietarily benefit from one of the state capitalism's properties (Johnson, 1982).Chinese growth strategies have backed up these strategic SOE. However, these features about financial repression have pressured on the allocation of capital and especially domestic small and medium firms have required pursuingother finance forms for their need of loans. Trusted on a severe of informal finance forms by private firms is not new event because Chinese strategies havebeen associated with financial repression since the earliest of reforms and many surveys have evidently proved these norms. For example, a survey conducted during the mid-1990s shows that almost some form of informal finance were used by two-thirds private firms; also, the recent survey applied in 2012 to understand of the magnitude and the spread of the informal finance forms poses that nearly 60 percent of private firms had engaged in informal finance mechanism ( $\mathrm{Li}$ and $\mathrm{Hu}, 2013$ ). The purpose of used informal finance forms have gradually transitivized for some reasons and new actors have participated in the informal finance 
forms;such as middle-class managers running after wealth management and local government encountering unfunded debt. Though the informal finance and shadow banks are neither regulated nor supervised by the People's Bank of China, they are not unlawful. In other words, with respect to China's context and concept, informal finance is associated with savings, financing and investment vehicles thatare not ratified but not banned(Tsai, 2002).

Especially after the tightened monetary policy reining in the volume of credit and decreasing in inflation, the systematic risk of shadow banks has been topical issue because the capacity of access to bank lending for SMEs dramatically diminished so that the SMEs have been totally forced to borrow underground. All of the economy situations have motivated the flourish of Chinese informal financial market.

Beijing government has decided on legitimating a financial reform package after the systematic of financial market resulted from the shadow banks not only dramatically raised, but also they will intend to increase the capacity of loan performance to small borrowers. Thus, in March 2012,the Beijing government have considered appropriate Wenzhou city (Figure 2) which is associated with informal lending and entrepreneurship. With aim of the financial reform package, the informal finance structure of the city will be legalized and allowing private lenders will be granted a right so that they are to run like investment companies to raise the loans to small and medium enterprises (SMEs)(Jielu and Mu,2013).

Figure 1:Wenzhou Underground Lending Market, by Use of Loan, as of June 2011

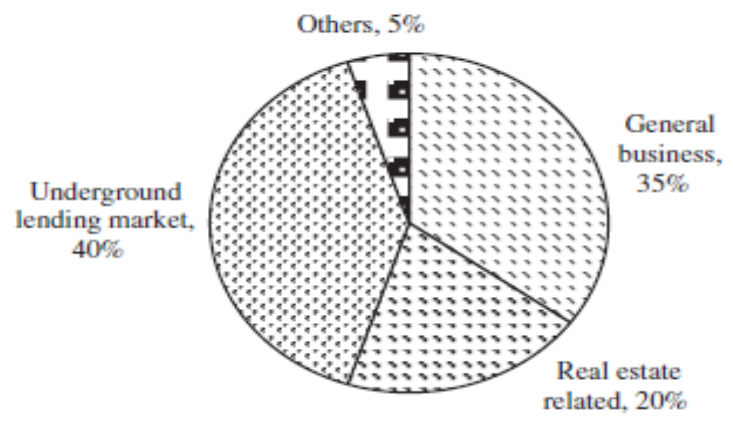

Sources: The Wenzhou Branch Office of the People's Bank of China 
Regarding to Chinese shadow banking, there are compounds which create a composition of informal lenders made out of $\mathrm{P}^{2} \mathrm{P}^{2}$,microfinance companies, trust companies, commercial banks and shadow currency(banks acceptance) ( lee 2016).That is, all of them refer to the shadow banking system. Initially,the P2P online lending system is originally came from the US. However, the P2P lending practices is quite different in China because US P2P lending platform is just able to provide information about finance intermediation service for either borrowers or lenders; namely, the US P2P lending system operates as a booster mechanism through posting or selecting borrowing and lending requests. Furthermore, Chinese P2P lending platform has been changed and improved by financial actors; indeed, Chinese system is rather different from both The US P2P and the lending practices of the traditional banks. Approach to the difference between the US and The China on the P2P lending platform, the Chinese $\mathrm{P} 2 \mathrm{P}$ is online or offline platforms which determine borrowers(online but mostly offline) and offer funds for lenders. The funds in the P2P platforms is mostly wealth management products (WMPs),similar to asset-backed securities, which is pursued by investor chasing higher investment returns(Gua and X1a,2011). The WMPs of the returns have higher return than loan interest. However, these fiancé activities have been by no means consented by the Chinese government; even this practices caused a credit crisis in Wenzhou not hearing of underground banking activates due to the WMPs default in 2011( Ren,2015).

Figure 2: Size of China's Shadow Banking Relative to Outstanding Bank Loans (in Trillions Yuan) by the End of 2011

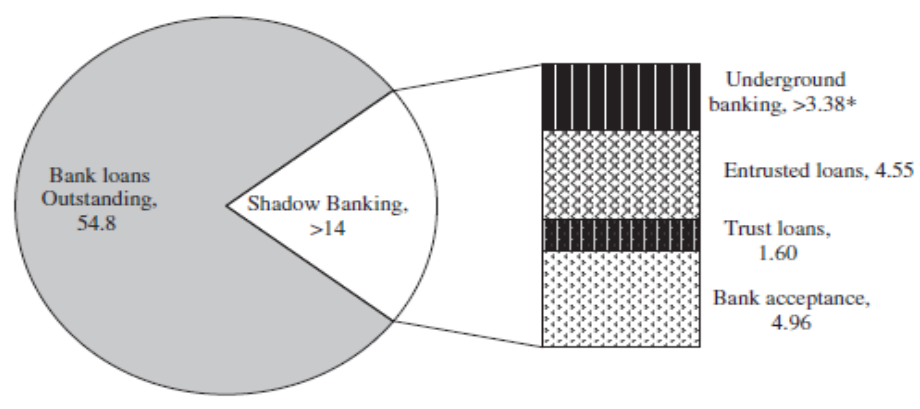

${ }^{2}$ The Peer-to-Peer Finance Association (P2P) is the industry association, which represents online debt-based alternative finance companies. 
Sources: People's Bank of China and CEIC.

Investors can also make an application to trust companies in order to invest in the WMPs because trust companies is also attractive due to higher return compared to savings deposits in banks. Trust companies are not required to set a reserve requirement in order to shield savers against loan defaults on contrary to the traditional banks. On the one hand, WMPs invested through trust companies are very vulnerable to economic conditions because WMPs returns are related capital-intensive ventures (Tsai, 2015).

Figure 3: Distribution of Shadow Banking Assets

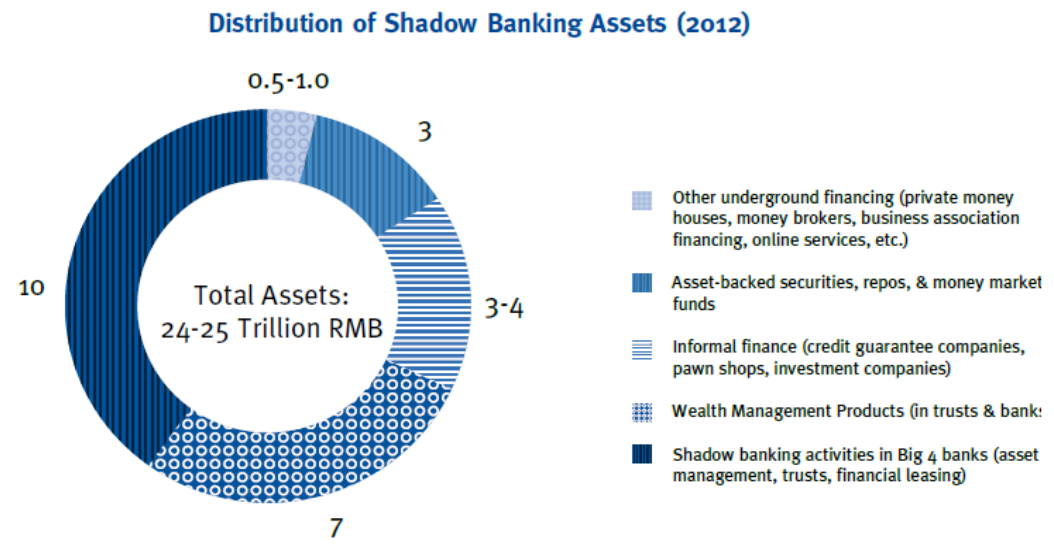

Source: Wang, B.L., \& Li, J.J. (2013).

Commercial bank financial productsare considered as relatively durable and less risky though banks take more risks than have been distinguished by customers. Although commercial banks products have lower default, analysts have been concern over the potential of these products because of some case of these product defaults. Commercial banks are well supervised and regulated but commercial banks are substantially engaged in shadow banking system through offering funds to trust and investment companies. Meanwhile, commercial banks convert their deposits into wealth management products to lend the converted funds to investors. The Chinese government have legislated a law in order to prevent the systematic risk resulting from commercial banks and the China Banking Regulatory Commission have intend to regulate the practice of commercial banks in the shadow banking system but enforcement in real terms lags the international standard(Brehm, 2008). 
A banks acceptance operates as a promised future payment. A non-financial company is able to get a banks acceptance from the bank by pledging 30-50 \% margin deposits and this acceptance later either sell or exchange in order to obtain cash to a buyer but a buyer is to wait until matures. This process not only remains beyond the off-balance sheet, but also commercial banks are able to modify margin rate so as to fix the regulatory ratio. Because of two actions, undiscounted bank acceptance have substantially fluctuated (Jielu and $\mathrm{Mu}$, 2010).

The microfinance companies have been main topic since 1998 for the Chinese government. The Chinese communist government had initiated a program and issued the guideline in order to boost the performance and curativeness of microfinance project so that the microfinance companies have been granted a legal status since 2008. On the other hand, the central government forbids accepting public deposits.In addition to this, the microfinance companies have been regarded as one of the most effective instrument in terms of poverty relieving factor and it is a good finance factor through meeting rural fiancé demand.However, the magnitude and spread of the microfinance companies has been converted into a factor impacting overall Chinese finance market (Rahman andLuo, 2012).

\section{The Contagion Effect Of The Boosted Shadow Banks}

Unlike to previous financial crisis, even the most advanced economies were vulnerable to the financial shock because ex-ante risk was not able to recognize due to high degree of leverage and outside regulation. The shadow banking system was regarded as stable hub but the network among financial actors in terms of off-balance sheet indeed was so big that the fragile of the system was totally disguised. The securitization process lead mortgage system to be liquid market and the instinct of profit rose among the financial actors. The shadow banking system created an intermediation a mechanism thatopens a huge profit area. Created intermediation without regulation and oversight induced systematic risks(Claessens et al, 2010)

Bordo and Wheelock(2007) historically prove that prolonged low interest rate is a classical initiative factor in terms of boosting the bubble of asset price and is considered as 
trigger financial crisis. When the argument is associated with the modern shadow market, the bubble of financial assets becomes more effective. Beginning with securitization process which real estate is converted in to liquid assets by, a low interest rate leads assets price and output to raise but eventually the process was reversed as tighten monetary policy causing low liquidity was conducted by The FED ( Calvo, 2009). The shadow banking was associated with the mortgage system prior to the financial crisis. Investment banks were integrated to the shadow banking system through repurchase agreements.For example,the hedge funds are important activities for investment banks in terms of higher return.However, the decrease in house price inducing the collapse of securitized mortgage system had contagion effect on highly leveraged investment banks, in turn, the mortgage system was subject to a deterioration which induced a increasing in haircuts and borrow against low-quality collateral became reverse,the shadow banking system associated with the mortgaged system collapsed and the global financial crisis raised from the dead (Pol, 2012). The collapse of Bear Stearns and the Lehman Brother is the most visible evidence in terms of cracked financial system.This argument show that the neglected financial risk through the shadow banking system caused a global financial crisis like an inevitable end (Gennaioli et al., 2013).

\section{Conclusion}

In this study, we aimed to identify the shadow banking system in China and their importance in the Chinese financial system. In order to implement reasonable policy, understanding of the properties of the shadow banking is quiet paramount. Because of the required, this study has beneficial effect on the literature. The subprime crisis has resulted in new discussion about Chinese activities because the shadow banking is one of the main factors to examine the crisis in addition to the risk taking in terms of the mortgage system. Indeed, the shadow banking is so similar to traditional banking system and financial intermediaries however the shadow banks do not expose to supervision and regulatory; thus, offering credit or loans by the shadow banks spread over the unsupervised financial areas. The shadow banking is so associated with the mortgage system; namely, they support each other. Generally, additional capital deployed by securitization was offered to the shadow banks and 
these unauthorized loans lead the leverage dramatically raise; hence, the economy around world became so vulnerable because of financial fragility.

In the study, the shadow banking systems have been tried to briefly examine and generate the features of the shadow banks. An important initial point to figuring out these systems is the Chinese state capitalism and its growth strategies. In China, a great number of loans are allocated to important industrial firms backed up by Chinese authorities so medium and small business is desperately needed of informal capital. As consequences of these properties, the shadow banks offered high costly loans to SME. Thus, the state capitalism in China caused the most financial notorious actors. In order to decrease financial risk all around work, the shadow banking system is key points so the regulatory and supervised are clearly an irreplaceable policy. Furthermore, the magnitude effect of the shadow banking on the 2008 financial crisis and the undesirable effect on financial market may be future research topics.

\section{References}

Board, S. F. S. R Gandhi (2014), “Danger Posed By Shadow Banking Systems To The Global Financial System - The Indian Case", International Conference "Governance \& Development: Views from G20 Countries", Mumbai.

Bordo, M. D., \& Wheelock, D. C. (2007), "Stock Market Booms And Monetary Policy In The Twentieth Century. Revive-Federal Reserve Bank of Saint Louis”, 89(2), 91122.

Brehm, S. (2008), "Risk Management in China's State Banks-international Best Practice And The Political Economy Of Regulation", Business and Politics, 10(1), 1-29.

Calvo, G. (2009), "Lender Of Last Resort: Put it On The Agenda”, VOX: March, 23, Retrieved from http://voxeu.org/article/establishing-global-lender-last-resort.

Claessens, S., Kose, M. A., \&Terrones, M. E. (2010), "Financial Cycles: What? How? When?", In NBER International Seminar on Macroeconomics 2010 (pp. 303-343).University of Chicago Press. 
Gennaioli, N., Shleifer, A., \&Vishny, R. W. (2013), "A Model Of Shadow Banking", The Journal of Finance, 68(4), 1331-1363.

Guo, L., \& Xia, M. D. (2014), "In Search Of A Place in The Sun: The Shadow Banking System With Chinese Characteristics", European Business Organization Law Review, 15(3), 387-418.

Jackson, B. F. (2013), “Danger Lurking in The Shadows: Why Regulators Lack The Authority To Effectively Fight Contagion in The Shadow Banking System", Harvard LawReview, 127(2), 729-750.

Johnson, C. (1982), MITI And The Japanese Miracle: The Growth Of Industrial Policy: 1925-1975, California: Stanford University Press.

Lee, E. (2015), "Shadow Banking System in China After The Global Financial Crisis: Why Shadow Banks Can Distort The Capital Market Order", Peking University Law Journal, 3(2), 361-384.

Li, J., \& Hu, F. (2013), "Financing Structure And Cost Of China's Small And Medium-Sized Enterprises And Development Of The Shadow Credit Market", Hongguanjingjiyanjiu [Macroeconomic research], 5, 7-11.

Pol, E. (2012), “The Preponderant Causes Of The USA Banking Crisis 2007-08”, The Journal of Socio-Economics, 41(5), 519-528.

Rahman, M. W., \&Luo, J. (2012), "Regulation Of Microfinance Service Provider in China And Bangladesh: An Approach To Strengthening The Regulatory Environment", African Journal of Business Management, Vol. 6, No. 3, pp. 1019-1033.

Ren, D. (March 23, 2015), "Banking Watchdog Mulls Tighter Rules on P2P Online Lending," South ChinaMorning Post, Retrievedfromhttp://www.scmp.com/business/chinabusiness/article/1744711/china-mullstighter-rules-booming-p2plending-business, lastvisited April 20, 2015. 
Tsai, K. S. (2002), “Back-Alley Banking: The Private Sector in Contemporary China”, NY: Cornell UniversityPress.

Tsai, K. S. (2015), “The Political Economy Of State Capitalism And Shadow Banking in China”, Issues\&Studies, 51(2), 55-97.

Tucker, P. (2012, April), "Shadow Banking: Thoughts For A Possible Policy Agenda", In speech at the European Commission High Level Conference, Brussels,(Vol. 27).

Wang, B.L., \& Li, J.J. (2013), "The Size Of Chinese Shadow Banking, Risk Assessment And Supervision", Journal of Central University of Finance \& Economics, 1(5), 20-25.

Weinland, D., \&Ren, D. (2015), "Banks Cautious About Easing Of Funding Rule in Shanghai Free-Trade Zone", South ChinaMorning Post. Retrieved from http://www.scmp.com/business/economy/article/1678398/npls-overwhelm-chinese-lendersstate-badbanks-look-other-way.

Yang, M., \& Yao, J. (2013), “China's Shadow Banking in Spotlight”, East Asian Policy, 5(4), 65-75. 